\title{
MEDICATION-TAKING BEHAVIOR AND DRUG SELF REGULATION IN PEOPLE WITH EPILEPSY
}

\author{
MARLEIDE DA MOTA GOMES*, HEBER DE SOUZA MAIA FILHO**
}

\begin{abstract}
Objective: To study the most important characteristics of antiepileptic drug (AED) taking behavior in epileptic people. Methods: In a cross-sectional study, 45 consecutively seen patients answered a standardized questionnaire including questions about drug intake behavior. Results: Both genders were equally represented $(22 \mathrm{M} \times 23 \mathrm{~F})$. The mean age was 30.2 years. No specific characteristic were presented in all patients. The selfreported non-use of the drug at any moment one week before (self-reported non-adherence) was $40.0 \%$. Patients took the drug more than once in most cases $(75.0 \%)$, and the only precipitating factor of seizures more frequently avoided was alcohol intake (66.7\%). Forty-four percent said to be afraid of becoming addicted to the medicine, $61.4 \%$ reduced or stopped the medicine just to see what would happen, and $47.7 \%$ changed the prescription with the same purpose. There is no relationship among socio-demographic, behavior aspects or treatment characteristics, and self-reported non-adherence. Conclusions: Several patient's aspects do not seem to be strongly correlated with self-reported adherence. Nevertheless, drug self-regulation is probably related to the drug-intake behavior, and it is important for the physician to understand this parallel influence on treatment for a more realistic approach.
\end{abstract}

KEY WORDS: epilepsy, adherence, antiepileptic drug.

\section{Comportamento de auto regulação da ingesta de medicamentos em pessoas com epilepsia}

RESUMO - Objetivo: Estudar as mais importantes características do comportamento de ingesta das drogas antiepilépticas (DAE) em pessoas com epilepsia. Método: Em estudo transversal, 45 pacientes consecutivamente vistos responderam a questionário padronizado sobre o comportamento de ingesta de DAE. Resultados: Ambos os sexos foram igualmente representados. A idade média foi 30,2 anos. Não há uma característica específica comum em todos os pacientes. O auto-referido não uso da DAE na semana anterior, em qualquer momento, (auto-referida não-aderência) foi de $40,0 \%$. Pacientes ingeriram a droga mais de uma vez, em muitos casos $(75,0 \%)$ e o único fator precipitante de crises epilépticas mais frequentemente evitado foi a ingesta de álcool $(66,7 \%)$. Quarenta e quatro por cento se diziam preocupados em se tornarem dependentes do medicamento, $61,4 \%$ reduziram ou suspenderam a DAE apenas para ver o que acontecia e $47,7 \%$ mudaram as prescrições com o mesmo propósito. Não houve relação entre características sócio-demográficas, aspectos comportamentais ou características de tratamento, e auto-referida não aderência. Conclusões: Vários aspectos dos pacientes não parecem estar relacionados fortemente com a aderência auto-referida. No entanto, a auto regulação da ingesta de drogas é provavelmente relacionada ao comportamento íntimo de sua ingesta, e é importante para o médico entender essa influência paralela no tratamento para uma abordagem mais realística.

PALAVRAS-CHAVE: epilepsia, aderência, droga antiepiléptica.

Low adherence to prescribed medication by the physician is considered the major cause of unsuccessful drug treatment in epilepsy ${ }^{1}$. This behavior is not particular to any specific disease, and it has no relationship to race, gender, age or disease severity, and its basis is not well understood ${ }^{2}$.

Epilepsy Program, Institute of Neurology; Clinical Epidemiology Program, Department of Internal Medicine - Faculty of Medicine, University Hospital, Universidade Federal do Rio de Janeiro: *Associate Professor, Medical Doctor, **Medical Doctor. This project was in part funded by the Rockefeller Foundation. Aceite: 9setembro-1998.

Dra. Marleide da Mota Gomes - Caixa Postal 68008 - CCS Bloco K Cidade Universitária - 21944-970 Rio de Janeiro RJ - Brasil. 
The definition of adherence relates both to medical recommendations and behavioral performance. Behavior related to individual's actions such as prescription refills and appointment keeping frequency are relatively straightforward to evaluate, but not all behaviors are easy to measure, such as actual medication intake.

In the field of epilepsy, several papers raise the issues related to measurement of adherence and its determinants ${ }^{3-5}$. The basis for understanding why individuals do or do not adhere to medical recommendations is studied in behavioral models such as the health care belief model that is the most frequently used one to evaluate variables related to patient adherence ${ }^{4}$.

The reasons for non-adherence, especially related to drug-intake behavior, is the major issue of our pilot study. In this way, we studied several variables of drug intake behavior to try to explain this complex question. Different forms of adherence evaluation are considered in another paper by the same authors ${ }^{6}$. Self-reported adherence is considered by many investigators as a good tool, but others report that patients tend to overestimate their adherence ${ }^{2,7}$. We use this type of evaluation in the present study.

\section{PATIENTS AND METHODS}

In a cross-sectional study, 45 patients consecutively seen at a specialized neurology clinic were selected from chart records to answer a structured questionnaire. To fulfill the inclusion and exclusion criteria to be enrolled in the study, it was necessary have had at least two witnessed seizures, to have EEG recording, to be 1160 years old and to be able to prepare and administer their own medication. Patients were excluded with any of the following conditions: acute or basic deteriorating neurological disease, chronic disease in long term therapy or malignant disease, epilepsy diagnosis not confirmed by clinical or EEG standards, alcoholism, psychosis, drug addiction, pregnancy, and motor or mental disease that could prevent voluntary participation in this study.

The items pool has been reduced by previous studies on adherence measures ${ }^{3-5,8}$ that have given us clues for the most consistent items of medication-taking behavior and other attributes related to adherence. Pre-tests were done. Patients were considered allegedly non-adherent if the following question was answered affirmatively: "Did you forget or miss any of your medicine last week ?". The answers to most were standardized: "strongly agree", "agree", "undecided", "disagree" or "strongly disagree". Then, they were dichotomized for the purpose of analysis. Questionnaires were applied by trained interviewers.

Statistical analysis for significant difference was used to compare two samples of the categorical data with the $\mathrm{X}^{2}$ and Ficher test. The proportion estimation precision was calculated by the exact binomial $95 \%$ confidence interval. The statistical package EPI 6 was used.

Table 1. Basic socio-demographic and clinical data.

\section{RESULTS}

The patients were equally distributed between genders, and the mean age was 30.2 years old. Regarding the level of education, the majority was capable of reading the prescribed medication, and had at least basic education. $33.3 \%$ had not presented seizures in the year before, and $48.9 \%$ had more severe cases (Table 1).

The patients took the drug more than once in the majority of cases $(75.0 \%)$, and the precipitating factor more frequently avoided was alcohol intake (Table 2). Although 77.8\% allegedly complied with treatment and $95.6 \%$ understood the prescription, $44.4 \%$ were afraid

\begin{tabular}{lcc}
\hline & \multicolumn{2}{c}{$\mathrm{n}=45$} \\
\hline Age (sd) & $\mathrm{n}$ & \\
\cline { 2 - 3 } & & \\
\cline { 2 - 3 } & & \\
Gender & 22 & \\
$\quad$ male & 23 & 49.0 \\
female & & 51.0 \\
& & \\
Level of education & 1 & 2.2 \\
illiterate & 24 & 53.3 \\
4 yrs spent at school & 20 & 44.4 \\
$>4$ yrs spent at school & & \\
Seizure frequency & & 33.3 \\
$\quad$ none & 15 & 17.8 \\
1 - 2/ year & 8 & 40.0 \\
$>3$ but not more 1 / month & 18 & 8.9 \\
$>1$ / month & 4 & \\
\hline
\end{tabular}


Table 2. Treatment characteristics.

\begin{tabular}{|c|c|c|c|}
\hline \multirow[t]{2}{*}{ Characteristics } & \multicolumn{3}{|c|}{$\mathrm{n}($ total $)=45$} \\
\hline & $\mathrm{n}$ & $\%$ & $\mathrm{CI}^{*}$ \\
\hline \multicolumn{4}{|c|}{ \#how frequently do you take your medicine? } \\
\hline once a day & 11 & 24.4 & $12.9-40.0$ \\
\hline twice a day & 16 & 36.4 & $21.9-51.2$ \\
\hline three times a day & 16 & 36.4 & $21.9-51.2$ \\
\hline four times or more & 2 & 4.5 & $0.5-15.1$ \\
\hline \multicolumn{4}{|c|}{ \#do you avoid possible precipitant factors of your seizures such as: } \\
\hline lack of sleep & 6 & 13.3 & $5.5-27.5$ \\
\hline fatigue & 5 & 11.1 & $3.7-24.1$ \\
\hline alcohol & 30 & 66.7 & $51.1-80.0$ \\
\hline nervousness & 4 & 8.9 & $2.5-21.2$ \\
\hline
\end{tabular}

${ }^{*} \mathrm{CI}$, coefficient interval.

Table 3. Medication-taking behavior.

Characteristics

$\mathrm{n}($ total $)=45$

\begin{tabular}{lccc}
\hline & $\mathrm{n}$ & $\%$ & CI* \\
\hline \# Did you forget or miss any of your medicine last week? & 18 & 40.0 & $25.7-55.7$ \\
\# Do you take the medicine the way the doctor tells you to? & 35 & 77.8 & $62.9-88.8$ \\
\#Do you ever stop your medication when you feel good? & 6 & 13.3 & $5.1-26.8$ \\
\#If you think the medicine makes you feel ill, do you ever stop taking it? & 6 & 13.3 & $5.1-26.8$ \\
\#Do you know exactly how to take your medicine? & 43 & 95.6 & $84.9-99.5$ \\
\#Do you think you can control your seizures without medicine? & 15 & 33.3 & $20.0-49.0$ \\
\#Does your family remind you to take your medicine? & 26 & 57.8 & $42.2-72.3$ \\
\# Are you afraid of becoming addicted to your medicine? & 20 & 44.4 & $29.6-60.0$ \\
\#Do you think that you can stop taking the medicine without any consequence? & 15 & 33.3 & $20.0-49.0$ \\
\#Do you think you can reduce or stop your medicine just to see what happens? & 27 & 61.4 & $44.3-74.3$ \\
\#Do you think you can change the prescription just to see what happens? & 21 & 47.7 & $31.7-62.1$ \\
\#Do you avoid or refuse to take the medicine in public? & 4 & 9.3 & $2.4-21.2$ \\
\hline
\end{tabular}

$\mathrm{CI}^{*}$, coefficient interval.

of becoming addicted, $61.4 \%$ thinks that they can reduce or stop the medication just to see what would happen (61.4\%) and $47.7 \%$ changed the prescription with the same purpose (Table 3 ). These behaviors, beliefs, gender, educational level, seizure frequency, frequency of drug intake, and time of the seizure did not bear any relationship with self-reported non-adherence (Table 4 and 5). Also, the frequency of drug intake was not correlated to omission frequency (Table 6). 
Table 4. Relationship between self-reported non-adherence and socio-demographic and treatment characteristics.

\begin{tabular}{|c|c|c|c|c|c|}
\hline \multirow[t]{3}{*}{ Characteristics } & \multicolumn{5}{|c|}{ Self-reported non-adherence } \\
\hline & \multicolumn{2}{|c|}{ yes } & \multicolumn{2}{|c|}{ no } & \multirow[b]{2}{*}{$\mathrm{p}$} \\
\hline & $\mathrm{n}$ & $\%$ & $\mathrm{n}$ & $\%$ & \\
\hline \multicolumn{6}{|l|}{ Gender } \\
\hline male & 9 & 40.9 & 13 & 59.1 & 0.9 \\
\hline female & 9 & 39.1 & 14 & 60.9 & \\
\hline \multicolumn{6}{|l|}{ Level of education } \\
\hline illiterate- 4 yrs spent at school & 10 & 40.0 & 15 & 60.0 & 1.0 \\
\hline$>4$ yrs spent at school & 8 & 40.0 & 12 & 60.0 & \\
\hline \multicolumn{6}{|l|}{ Fear of addiction } \\
\hline yes & 7 & 35.0 & 13 & 65.0 & 0.5 \\
\hline no & 11 & 44.0 & 14 & 56.0 & \\
\hline \multicolumn{6}{|c|}{ Reduction or interruption of medicine } \\
\hline yes & 12 & 44.4 & 15 & 55.6 & 0.5 \\
\hline no & 6 & 33.3 & 12 & 66.7 & \\
\hline \multicolumn{6}{|l|}{ Change of prescription } \\
\hline yes & 7 & 33.3 & 14 & 66.7 & 0.5 \\
\hline no & 10 & 76.9 & 3 & 23.1 & \\
\hline \multicolumn{6}{|l|}{ Drug intake frequency } \\
\hline $1-2$ & 11 & 42.3 & 15 & 57.7 & 0.9 \\
\hline$\geq 3$ & 8 & 44.4 & 10 & 55.6 & \\
\hline
\end{tabular}

Table 5. Comparison between self-reported adherence and other characteristics.

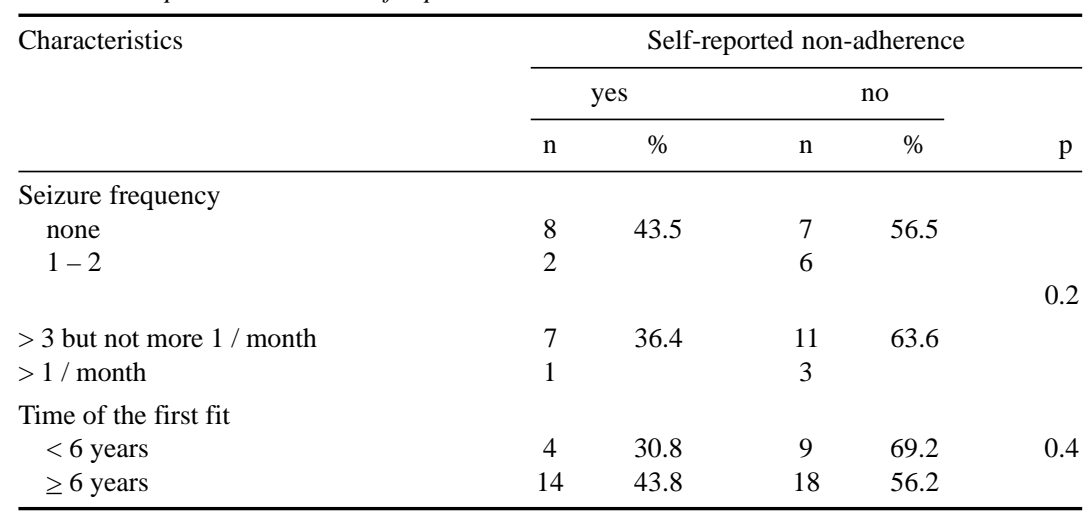

Table 6. Comparison between omission frequency and frequency of the drug intake.

\begin{tabular}{|c|c|c|c|c|c|}
\hline \multirow[t]{3}{*}{ Omission frequency } & \multicolumn{5}{|c|}{ Intake frequency } \\
\hline & \multicolumn{2}{|c|}{$1-2$} & \multicolumn{2}{|c|}{$\geq 3$} & \multirow[b]{2}{*}{$\mathrm{p}$} \\
\hline & $\mathrm{n}$ & $\%$ & $\mathrm{n}$ & $\%$ & \\
\hline None & 17 & 63.0 & 10 & 37.0 & \\
\hline Unknown & 1 & 55.6 & 3 & 44.4 & \\
\hline $1-2$ & 6 & & 4 & & \\
\hline$\geq 3$ & 3 & & 1 & & \\
\hline
\end{tabular}




\section{DISCUSSION}

Our study, not differently from any other on this issue, has the primary difficulty of defining who is adherent or not adherent. Here, we use only the self-reported adherence, understanding that it is simply a crude approximation of the real (and floating) behavior. Indeed, we are dealing with extremes of adherence, because total adherence to medical prescription is probably rare, and it is not more than a continuous behavior rather than one dichotomous outcome ${ }^{1}$. We understand that the low adherence is underestimated in our study (40\%). It is recognized that the reliability is higher when the patient reports changing the medication than when reporting not taking the medication as prescribed. A study of pooled data relating self-reported adherence to pill count demonstrated that: the self-reported adherence as a test had $55 \%$ of sensitivity, about $87 \%$ of specificity and 4.4 of likelihood ratio in cases of positive tests ${ }^{2}$. Another problem in our study, common to others in the same area, is the low sample size available to evaluate significant differences among groups with defined characteristics.

Difficulty in taking the drug frequently is understandable and this could be a disadvantage for the full adherence ${ }^{4}$. However, our study cannot prove adherence to be a function of the amount or frequency of drug intake. As a whole, our patients underestimate the role of life-style habits in controlling crises, despite caution with alcohol intake in $66.7 \%$. Interestingly, correct understanding of drug prescription and usage does not prevent altered antiepiletic drug administration patterns due to independent self-control behavior by some patients. The reason for this could be the feeling of being addicted with the continuous use of the drugs, to test the treatment or the diagnosis of epilepsy itself ${ }^{9}$. These behaviors, do not seem linked to gender, educational level, and may be more situation related, as reported by Conrad ${ }^{10}$ and Trostle ${ }^{9}$. The severity of the disease does not take part in this behavior, as shown in our study, but Peterson and col. ${ }^{5}$ related it to compliance. Takaki and col. ${ }^{8}$ did not show correlation between adherence and type of seizure, unlike Peterson and col. ${ }^{5}$.

Therefore, there are two ways to regard adherence: the physician and the patient perspective; both of them have also different risk-benefit views. Usually, the study of adherence has only a physician's perspective. Indeed, patients are determinant of their own treatment and actively take part in it. As our study points out, although patients say they understand how to take their medication, many of them change their prescriptions according to their own beliefs in an attempt to learn the limits of their medications. Mainly social scientists study this paradox, and question the physician health care centered power in detriment of the patient's will ${ }^{9-12}$. In reality, patients can have an alternative approach that could be efficacious. Our study also presents this type of analysis and shows how complex could be the behavior of these patients, at the same time saying that they understood the prescription but following their own rules.

Our results suggest that it is always useful to negotiate with the patient and reach an agreement about an intermediate behavior that lies between the ideal - yet fictitious - proposed by the physician, and the more realistic one that contemplates personal beliefs of patients and that also may be turn out to be more therapeutically efficacious. Drug-intake behavior is multifactorial. Consequently, only by listening carefully to patients could the doctor gather enough clues to determine the issues to be agreed in the prescription. Self determination is important for compliance with the prescription, and the physician must recognize how influent the patient's perspective and point of view could be on the final and real drug intake behavior.

Acknowledgments - We acknowledge the collaboration of the out-patient clinic staff at the Institute of Neurology of Universidade Federal do Rio de Janeiro, the important comments made by Professor Brian Haynes, and the help of Dr. Fernando Machado Rodrigues in the preparation of the manuscript. 


\section{REFERENCES}

1. Leppik IE. Compliance in the treatment of epilepsy. In E Wyllie (eds). The treatment of epilepsy: principles and practice. 2.Ed. Baltimore: Wiliams and Wilkins, 1996:779-784.

2. Stephenson BJ, Rowe BH, Haynes RB, Macharia WM, Leon G. Is this patient taking treatment as prescribed? JAMA 1993;269:2779-2781

3. Eisler J, Mattson RH. Compliance in anticonvulsivant drug therapy. Epilepsia 1975;16:203.

4. Bryant SG, Ereshefsky L. Determinants of compliance in epileptic outpatients. Drug Int Clin Pharm 1981;15:572-577.

5. Peterson GM, Mclean S, Millingen KS. Determinants of patient compliance with anticonvulsant therapy. Epilepsia 1982; 23:607-613.

6. Gomes MM, Maia Fo HS, Noé RAM. Epileptic drug intake adherence evaluation: the clinical value of the serum drug level. Arq Neuropsiquiatr 1998;56:708-713.

7. Haynes RB, Taylor W, Sackett DL, Gibson ES, Bernholtz DC, Mukherjee J. Can simple clinical measurements detect patient noncompliance. Hypertension 1980;2:757-764.

8. Takaki S, Kurokawa T, Aoyama T. Monitoring drug compliance in epileptic patients: assessing phenobarbital levels. Drug Monit 1985;7:87-91

9. Trostle J. Doctors' orders and patients self-interest: two views of medication usage? Epilepsy Res 1988;1(Suppl):57-69.

10. Conrad P. The meaning of medications, another look at compliance. Soc Sci Med 1985;20:29-37.

11. Trostle JA. Medical compliance as an ideology. Soc Sci Med 1988; 27:1299-1308.

12. Trostle JA, Hauser WA, Susser IS. The logic of noncompliance: management of epilepsy from the patient's point of view. Cult Med Psychiatry 1983;7:35-56. 